DOI: https://doi.org/10.31933/jimt.v2i2

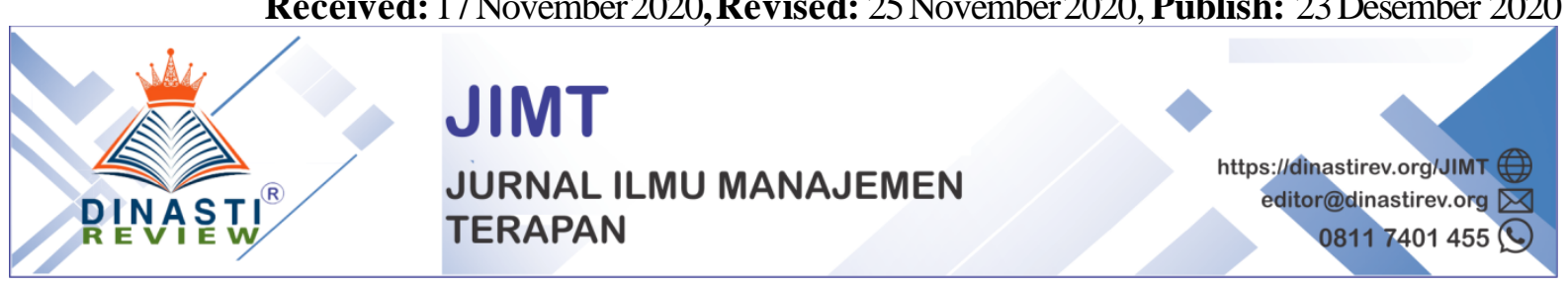

Received: 17 November 2020, Revised: 25 November2020, Publish: 23 Desember 2020

\title{
MANAJEMENSTRATEGI PERUBAHAN LEMBAGA PENDIDIKAN ISLAM PADA PASCASARJANA UIN STS JAMBI
}

\author{
Darwisyah $^{1}$, Ita Tryas Nur Rohcbani ${ }^{2}$, Desvitasari ${ }^{3}$, Armawati $^{4}$, Maisah $^{5}$ \\ ${ }^{1}$ Dr. Student Program at UIN STS Jambi, email; ewibafadhal@ gmail.com \\ ${ }^{2}$ Dr. Student Program at UIN STS Jambi, email; ita.rochbani89@gmail.com \\ ${ }^{3}$ Dr. Student Program at UIN STS Jambi, email; akmaldesvitasari@ gmail.com \\ ${ }^{4}$ Dr. Student Program at UIN STS Jambi, email; armawati217@gmail.com \\ ${ }^{5}$ Lecturer at UIN STS Jambi, email; Maisahmaisah123@gmail.com
}

\section{Corresponding Author: Darwisyah}

Abstrak: Dalam kajian ini penulis mencoba mengangkat permasalahan yang mempengaruhi manajemen strategi perubahan pada lembaga pendidikan islam yaitu Pascasarjana UIN Jambi. Penulis mencoba mengidentifikasi faktor-faktor apa saja yang dapat mempengaruhinya. Dalam penelitian ini penulis menggunakan metode penelitian kepustakaan atau library research. Selain bersifat kepustakaan, penelitain ini juga bersifat kualitatif. Karena yang di hasilkan adalah bersifat deskriptif analitis. Yaitu memaparkan permasalahan secara apa adanya berdasarkan pada sumber-sumber rujukan otoritatif dalam bidang pendidikan, sesuai teori yang di teliti. Dan hasil menujukan bahwa adanya faktor penghambat dalam menjalankan perubahan. Dari mulai level bawah sampai level tertinggi.

Kata Kunci: Manajemen, Strategi, Perubahan, Pascasarjana UIN STS Jambi.

\section{PENDAHULUAN}

Sumber daya manusia (SDM) merupakan salah satu faktor penting dalam pembangunan. Secara makro, faktor-faktor masukan pembangunan, seperti sumber daya alam, material dan finansial tidak akan memberi manfaat secara optimal untuk perbaikan kesejahteraan rakyat bila tidak didukung oleh memadainya ketersediaan faktor SDM, baik secara kualitas maupun kuantitas. Pelajaran yang dapat dipetik dari berbagai negara maju adalah, bahwa kemajuan yang dicapai oleh bangsa-bangsa di negaranegara tersebut didukung oleh SDM yang berkualitas.

Dimensi berubah merupakan suatu konsekuensi logis dalam kehidupan yang terus akan berkembang sejalan dengan perjalanan waktu dan usia manusia. Begitu pula halnya dengan tidak berubah atau statis, maka hal tersebut menandakan bahwa manusia itu keras, susah diatur, mau menang sendiri, selalu menganggap dirinyalah yang paling benar, melebihi segala-galanya. Namun, inilah fenomena yang terjadi dalam sebuah lembaga ada yang memilih untuk berubah adapula yang menolak akan perubahan tersebut. 
Pengembangan SDM pada intinya diarahkan dalam rangka meningkatkan kualitasnya, yang pada gilirannya akan dapat meningkatkan produktivitas. Hasil berbagai studi menunjukkan, bahwa kualitas SDM merupakan faktor penentu produktivitas, baik secara makro maupun mikro. Sumber Daya Manusia (SDM) secara makro adalah warga negara suatu bangsa khususnya yang telah memasuki usia angkatan kerja yg memiliki potensi untuk berperilaku produktif (dengan atau tanpa pendidikan formal) yg mampu memenuhi kebutuhan hidup sendiri dan keluarganya yang berpengaruh pada tingkat kesejahteraan masyarakat di lingkungan bangsa atau negaranya.

Albert einstein mengatakan bahwa sesuatu yang pasti adalah perubahan (Einstein, 2013). Sedangkan Evelyn Waugh menyatakan change is the only evidence of life. Perubahan merupakan keniscayaan bagi kehidupan manusia.Sejarah peradaban manusia selalu ada fasefase perubahan, begitu juga sejarah peradaban Islam yang selalu menghadapi dan berhadap hadapan dengan perubahan.Rhenald Kasali dalam bukunya Change, menulis bahwa "tak peduli berapa jauh jalan salah yang anda jalani, putar arah sekarang juga."(Waugh \& Austen, 2014).

Maqolahyang terkenal yang menjadi prinsip bagi warga Nahdlatul ulama almuhafadzatu qodim solih wal akhdu bil jadid aslah "menjaga yang terdahulu yang baik dan mengambil yang baru yang lebih baik". Ini menjadi dasar bahwa perubahan untuk menjadi lebih baik itu menjadi keharusan.Hal ini pun, berlaku dalam perubahan pada lembaga pendidikan khususnya yang menjadi kajian pada makalah ini adalah Perguruan Tinggi.

Pendidikan merupakan lembaga pendidikan yang berkembang pada saat kegemilangan Islam tepatnya pada zaman Abbasiyah terkenal dengan Perguruan Tinggi Nidzom al-mulk (Alfan Zuhairini, 2011). Seiring perkembangan zaman pengelolaan pada Perguruan Tinggi pun idealnya berkembang mengikuti perkembanganzaman.Dinamis dan fleksibel sesuai kebutuhan zaman, pengelola/ manajer harus mampu melakukan perubahanperubahan dalam mengelola Perguruan Tinggi. Hanya, Persoalan berikutnya adalah bagaimana perubahahan tersebut harus dikelola.

Memahami manajemen dan perubahan merupakan kebutuhan mutlak bagi perkembangan lembaga pendidikan (Perguruan Tinggi).Pemahaman tentang manajemen perubahan diperlukan agar kemungkinan keberhasilan suatu usaha upaya perubahan lebih besar.Termasuk perubahan dalam lemabaga pendidikan Islam (Perguruan Tinggi) harus dapat dikelola dengan baik, sehingga Perguruan Tinggi tidak tertinggal oleh lemabag-lemabaga pendidikan yang lainnya.Untuk itu, manajemen prubahan perlu mengambil dari pelajaran sebelumnya, menjalankan proses perubahan dengan benar, dan memberikan peran dan tanggungjawab kepada semua stakeholder sesuai dengan proporsinya. Oleh karena itu penulis dapat merumuskan kedalam suatu rumusan masalah yaitu:

1. Apakah manajemen perubahan berpengaruh terhadap Pasca Sarjana UIN Jambi?

2. Apakah strategi perubahan berpengaruh terhadap Pasca Sarjana UIN Jambi? 


\section{KAJIAN PUSTAKA}

\section{Manajemen Perubahan}

Menurut Winardi, menyatakan bahwa manajemen perubahan adalah suatu konsep perubahan yang di rencanakan (Planned Change) dan perubahan yang tidak di rencanakan (Unplanned Change) yang dilakukan individu atau kelompok dari keadaan sebelumnya menjadi keadaan setelahnya.(Winardi, 2004).

Menurut Pidarta, menyatakan bahwa manajemen perubahan adalah suatu usaha yang dilakukan oleh seorang pemimpin atau manajer dalam menyusub sebuah perencanaan, koordinasi, pengarahan, kontrol/pengawasan untuk mencapai sasaran atau tujuan yang dapat menjadikan sebuah organisasi atau lembaga menjadi lebih baik dari kemarin untuk mencapai tujuan.(Pidarta, 1997). Dari uraian di atas maka seorang manajer dalam mencapai tujuan manajemen perubahan sangatlah mudah. Selain itu Pidarta juga menjelaskan bahwa untuk mewujudkan sebuah manajemen perubahan dalam sebuah organisasi atau lembaga, seorang manajer juga harus harus memiliki empat ketrampilan dalam menyusun sebuah konsep yaitu menentukan strategi, membuat sebuah kebijakan yang tegas, mengkreasikan atau merencanakan suatu yang baru; dan memutuskan.(Muis et al., 2010)

Menurut Hamalik menyatakan bahwa manajemen perubahan merupakan perencanaan suatu rangkaian tindakan untuk ke depan atau masa yang akan datang. Perencanaan tersebut bertujuan untuk mencapai seperangkat operasi yang konsisten dan terkoordinasi guna memperoleh hasil-hasil yang diinginkan.Dan perencanaan itu disusun oleh seorang manajer atau Perguruan Tinggi.(Hamalik (2010: 29) dalam Baharudin, 2015).

\section{Strategi perubahan}

Perubahan sosial berkaitan degan teori perspektif struktural fungsional. Pandangan tersebut bahwa masyarakat adalah sebuah sistem yang stabil dan memiliki tatanan sosial relatif stabil dan terintegrasi dalam kehidupan sehari- hari. Pada pandangan tersebut terlihat bahwa kestabilan dan keteraturan dalam kehidupan masyarakat dianggap sebagai kondisi dan situasi yang stabil dan perubahan yang terjadi dalam kehidupan masyarakat sebagai penyimpangan. Menurut perspektif struktural fungsional bahwa perubahan sosial diabaikan dalam kehidupan masyarakat dan masyarakat dalam kondisi yang statis atau tetap untuk melakukan aktivitas kehidupan (Indraddin \& Irwan, 2016). Pemahaman teori perspektif struktural fungsional bahwa masyarakat merupakan sistem yang berada dalam keseimbangan (equiliberium). Mekanisme yang dimiliki oleh masyarakat menjadikan dirinya dan menempatkan posisi serta kemampuan tetap dalam situasi dan kondisi yang seimbang. Dengan demikian, jika dalam kehidupan masyarakat melakukan perubahan secara cepat mengakibatkan rusaknya sistem (Muhammad Arifin, 2017).

Seorang memahami sosiologi tidak hanya melihat masalah sosial pada satu sisi, melainkan banyak sisi yang mempengaruhi seseorang melakukan tindakan. Tindakan tersebut tidak hanya dilakukan sendiri pasti ada pengaruh yang besar, sehingga sesorang mengambil 
sikap dan pilihan hidup dalam mencapai standar kehidupan yang baik (Aminuddin Awang Kechik, 2011). Sudut pandang sosiologi bahwa topik kajian interaksi sosial cukup menarik untuk kita bahas dalam topik perubahan sosial, hal ini terkait perubahan sosial yang terjadi sebuah proses membentuk kenyataan sosial. Memahami itu semua, bahwa interaksi sosial sebagai jalan yang luas dan sebagai dasar untuk berpijak atas peristiwa yang terjadi (Arifin, 2017; Indradd in \& Irwan, 2016).

\section{Tantangan Global Lembaga Pendidikan Islam}

Menurut Agus Rahayu pergeseran lingkungan dan kekuatan persaingan dalam industry pendidikan menyebabkan timbulnya kesenjangan tuntutan (Rahayu, 2010). Situasi ini telah memaksa sebagian satuan pendidikan mengurangi atau menghentikan operasinya. Sejumlah program studi pada perguruan tinggi mengalami penurunan mahasiswanya, bahkan terpaksa ditutup dan atau di cabut izin operasionalnya. Ini terjadi pula pada satuan pendidikan lainya (Indrawati, 2011).

Maka dari itu ada manajemen strategis untuk menghadapi tantangan global tersebut, ada beberapa hal sebagai berikut: Pertama, model strategis a) Model market-based, bahwa kondisi dan karakteristik lingkungan eksternal merupakan input utama dalam penentuan strategi untuk mencapai tujuan organisasi, b) Model resource-based, bahwa lingkungan internal atau sumber daya internal merupakan input utama dan penentu strategi untuk mencapai tujuan organisasi. Kedua, strategi untuk meraih keunggulan suatu lembaga pendidikan Islam yaitu Strategi bersaing (competitive strategy) dan Strategi bekerja sama (cooperative strategy). Keputusan strategi yang dipilih dan diimplementasikan di dasarkan pada sumber daya yang lebih baik (superior resources). Apabila sumber daya yang dimiliki imperior (imperior resources) maka cooperative strategy tepat untuk dipilih. Dalam situasi sumber daya yang relative sama dengan yang lain maka pertimbangan pilihan strategi lebih focus pada daya Tarik pasar (Assauri, 2011).

\section{METODE PENELITIAN}

Metode penelitian artikel ilmiah ini adalah dengan metode studi literature atau Library Research. Yaitu mengkaji Buku-buku literature sesuai dengan teori yang di bahas pada tema artikel (Nasution, 2002). Disamping itu menganalisis artikel-artikel ilmiah yang bereputasi dan juga artikel ilmiah dari jurnal yang belum bereputasi. Semua artikel ilmiah yang di citasi bersumber dari sumber kepustakaan dari Mendeley dan Google Scholar.

Selain bersifat kepustakaan, penelitain ini juga bersifat kualitatif. Karena yang di hasilkan adalah bersifat deskriptif analitis. Yaitu memaparkan permasalahan secara apa adanya berdasarkan pada sumber-sumber rujukan otoritatif dalam bidang pendidikan, sesuai teori yang di teliti (Suharsimi, 2013) (Hapzi Ali. Nandan Limakrisna, 2013).

HASIL DAN PEMBAHASAN

\section{Manajemen Strategi Perubahan Pascasarjana UIN STS Jambi}


Menurut Ahmad syukri \& Maisah menyatakan bahwa faktor-faktor penyebab peubahan disebabkan adanya kekuatan eksternal dan internal, yang saling berinteraksi hingga mereka saling memperkuat antara satu sama lainnya. Para manajer bereaksi antara faktorfaktor tersebut, sering kali menimbulkan dampak-dampak penting antara individu-individu, yang ada dalam organisasi yang bersangkutan.Guna bertahan dan berkembang, maka organisasi perlu bereaksi dan menyesuankan diri terhadap berbagai macam kekuatan tersebut.Mereka perlu melaksanakan kegiatan inovasi dan berkesinambungan memperbaiki produk serta jasa-jasa mereka guna memenuhi permintaan konsumen yang berubah dan guna menghadapi pihak-pihak pesaing (Ahmad Syukri, Maisah, 2020).

Menurut Sari dan ibrahim, menyatakan bahwa manajemen perubahan adalah mengimplementasikan sebuah strategi dan menganalisis sebuah perubahan yang mungkin akan dialami perusahaan atau sebuah lembaga pendidikan akibat dari formulasi strategi yang telah disepakati pada tahap sebelumnya. Analisis tentang perubahan ini bertujuan untuk memberikan sebuah gagasan yang jelas dan terperinci mengenai seberapa banyak perusahaan atau sebuah lembaga pendidikan harus berubah berhasil dalam mengimplementasikan sebuah strategi (Sari \& Ibrahim, 2009).

Menurut Winardi penyebab terjadinya perubahan, disebabkan oleh beberapa faktor lingkungan, diantaranya: pertama; faktor ekonomi, Keadaan ekonomi suatu negara akan mempengaruhi kinerja perusahaan dan industri. Faktor ekonomi mengacu kepada sifat, cara dan arah dari perekonomian dimana suatu perusahaan akan atau sedang berkompetisi. Kedua; faktor sosial, faktor-faktor sosial mempengaruhi suatu perusahan mencakup keyakinan, nilai, sikap, opini yang berkembang, dan gaya hidup dari orang-orang di lingkungan dimana perusahaan beroperasi. Ketiga; faktor politik dan hukum, arah dan stabilitas dari faktor politik dan hukum merupakan pertimbangan utamabagi manajer dalam memformulasikan strategi perusahaan. Faktor politik dan hukum mendefinisikan parameter hukum dan bagaimana pengaturan perusahaan melalui keputusan perdagangan yang wajar, program perpajakan, penentuan upah minimum, kebijakan polusi dan harga serta banyak tindakan lainnya yang bertujuan untuk melindungi karyawan, konsumen, masyarakat umum dan lingkungan. Keempat; faktor teknologi, faktor tenologi sebagaimana faktor-faktor lain dalam lingkungan umummerefleksikan kesempatan dan ancaman bagi perusahan. Kemajuan teknologi secara dramatis telah mengubah produk, jasa pasar, distributor, pesaing, pelanggan, proses manafaktur, praktik-praktik pemasaran dan posisi persaingan.(Winardi, 2017).

Dari ke empat faktor lingkungan yang menyebabkan perubahan dalam suatu perusahaan atau lembaga, maka perubaha tersebut sangatlah mudah dan dapat tercapai tujuan yang diingingkan.nDalam menyusun sebuah perencanaan yang baik seorang manajer harus memperhatikan 5 unsur khususyaitu Tujuan di rumuskan secara jelas, Komprehensif namun jelas bagi staf dan anggota organisasi, Hierarki rencana yang terfokus pada daerah yang paling penting, Bersifat ekonomis, mempertimbangkan sumber-sumber yang tersedia, Layak, memungkinkan perubahan.

\section{Analisis SWOT Pascasarjana UIN STS Jambi}


Maisah menyatakan, Analisis SWOT adalah suatu metode perencanaan strategis yang digunakan untuk mengevaluasi Kekuatan (Strength) Kelemahan (Weaknesses) Peluang (Oppoturuities) Ancaman (Threats) dalam suatu lembaga pendidikan (Maisah et al., 2020) Sedangkan menurut kotler Analisis SWOT adalah penilaian menyeluruh terhadap kekuatan (strenghts), kelemahan (weaknesses), peluang (opportunities) dan ancaman (threats) suatu perusahaan atau lembaga (Kotler \& Armstrong, 2012). Berikut ialah analisis SWOT Pascasarjana UIN STS Jambi;

\section{Tabel.1 Analisis SWOT}

\begin{tabular}{|c|c|c|}
\hline $\begin{array}{l}\text { Faktor } \\
\text { Eksternal }\end{array}$ & $\begin{array}{l}\text { Kekuatan/Strength: } \\
\text { 1. Berada di Kota. } \\
\text { 2. Memiliki pemimpin yang } \\
\text { visioner. } \\
\text { 3. Memiliki Dosen Profes or } 12 \\
\text { orang, dan Doktor } 26 \text { orang. } \\
\text { 4. Memiliki fasilitas perkuliahan } \\
\text { yang representative. } \\
\text { 5. Memiliki } 2 \text { program studi S3, } \\
5 \text { program studi S2 } \\
\text { 6. Akreditasi B. }\end{array}$ & $\begin{array}{l}\text { Kelemahan/Weakness: } \\
\text { 1. Akreditasi Institut B. } \\
\text { 2. Jumlah mahasiswa masih } \\
\text { sedikit. } \\
\text { 3. Kurangnya animo masyaraka } \\
\text { tentang pendidikan. }\end{array}$ \\
\hline $\begin{array}{l}\text { Opportumin: } \\
\text { 1. Menjadikan perguruan } \\
\text { tinggi dengan lokomotif } \\
\text { perubahanunggul } \\
\text { berbasis } \\
\text { Intrepreneurship. } \\
\text { 2. Terbukanya peluang } \\
\text { kerjasama dengan } \\
\text { perguruan tinggi lain } \\
\text { baik dalam Negeri } \\
\text { maupun Luar Negeri. }\end{array}$ & $\begin{array}{l}\text { Strategi SO: } \\
\text { 1. Mengembangkan prodi yang } \\
\text { sudah ada (O4). } \\
\text { 2. Meningkatkan kegiatan- } \\
\text { kegiatanyang membangun } \\
\text { animo masyarakat (O2, S2, } \\
\text { S3). } \\
\text { 3. Membangun gedung dan } \\
\text { fasilitas yang dibutuhkan (O4, } \\
\text { S2) }\end{array}$ & $\begin{array}{l}\text { Strategi WO } \\
\text { 1. Mengajukan alkreditasi } \\
\text { Instituti dan Prodi (W1, O4) } \\
\text { 2. Mengembangkan prodi dan } \\
\text { meningkatkan sosialisasi } \\
\text { (W2, O4). } \\
\text { 3. Mengembangkan unit usaha. }\end{array}$ \\
\hline $\begin{array}{l}\text { Ancaman (Threats) } \\
\text { 1. Tidak bisa bersaing } \\
\text { dengan perguruan } \\
\text { tinggi lain. } \\
\text { 2. Hilangnya kepercayaan } \\
\text { masyarakat. } \\
\text { 3. Bisa tertingalnya } \\
\text { perguruan tinggi. }\end{array}$ & $\begin{array}{l}\text { Strategi }(S T) \\
\text { 1. Mempromosikan prodi yang } \\
\text { ada sesuai dengan kebutuhan } \\
\text { masyarakat. } \\
\text { 2. Mengoptimalkan lulusan dari } \\
\text { berbagai prodi yang ada. }\end{array}$ & $\begin{array}{l}\text { Strategi (WT) } \\
\text { 1. Memiliki mahasiswa yang } \\
\text { banyak (W2) } \\
\text { 2. Kesejahteraan Dosen harus } \\
\text { diutamakan (W4, T3) }\end{array}$ \\
\hline
\end{tabular}

\section{Kerangka Konseptual \& Hipotesis}

Berdasarkan kajian teori dan hubungan antar variabel maka model atau kerangka konseptual artikel ini dalam rangka membagun hipotesis adalah sebagai berikut:

1) Pengaruh manajemen perubahan terhadap Pascasarjana UIN STS Jambi berdasarkan hasil riset: (Arifin, 2017; Artini, 2015; Dalimunthe, 2013; Dewi \& Kurniawan, 2019; Edison et al., 2016; Kotler \& Keller, 2009; Mathis \& Jackson, 2012; Muhammad 
Arifin, 2017; Muslich, 2003; "PENGARUH PERKEMBANGAN TEKNOLOGI INFORMASI TERHADAP BIDANG AKUNTANSI MANAJEMEN," 2000; Sari \& Ibrahim, 2009; Sumarwan, 2003; Tambunan et al., 2011; Widodo, 2017).

2) Pengaruh strategi perubahan terhadap Pascasarjana UIN STS Jambi berdasarkan hasil riset; (Abdurrahman, 2015; Anggareni et al., 2013; Gunanto, 2013; "HUBUNGAN KEPEMIMPINAN, BUDAYA, STRATEGI, DAN KINERJA: PENDEKATAN KONSEP," 2005; Narsa, 2014; Nisak, 2004; Peter \& Olson, 2013; Tjiptono \& Fandy, 1997, 2015; Wedhasmara, 2014; Wibowo et al., 2015).

Dari rumusan masalah penulisan artikel ini dan kajian studi literature review baik dari buku dan artikel yang relevan, maka di perolah rerangka artikel ini seperti di bawah ini.

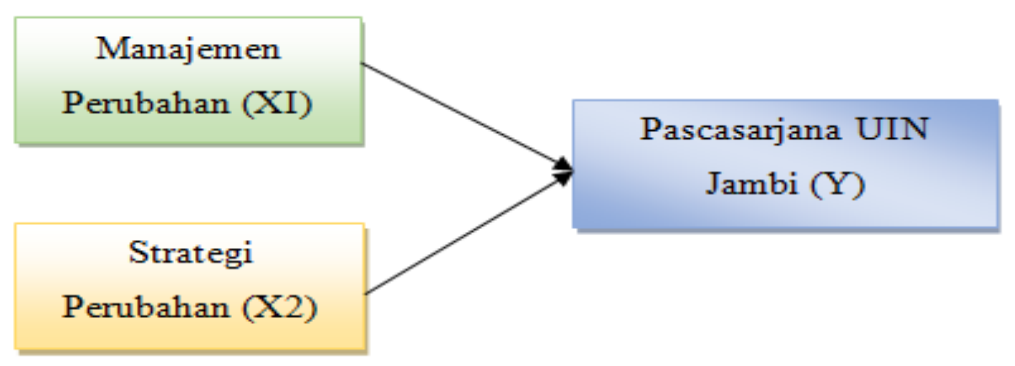

\section{Gambar 1: Kerangka Konseptual}

Berdasrakan Kajian teori, review hasil riset dari jurnal yang relevan serta gambar dari conceptual framework, maka dapat di rumuskan hipotesis untuk riset selanjutnya yaitu:

1. Manajemen perubahan berpengaruh terhadap Pasca Sarjana UIN Jambi.

2. Strategi perubahan berpengaruh terhadap Pasca Sarjana UIN Jambi.

\section{KESIMPULAN DAN SARAN}

\section{Kesimpulan}

Konsep dasar manajemen perubahan adalah mengimplementasikan sebuah strategi dan menganalisis sebuah perubahan yang mungkin akan dialami perusahaan atau sebuah lembaga pendidikan akibat dari formulasi strategi yang telah disepakati pada tahap sebelumnya. Perubahan ini bertujuan untuk memberikan sebuah gagasan yang jelas dan terperinci mengenai seberapa banyak sebuah lembaga pendidikan harus berubah berhasil dalam mengimplementasikan sebuah strategi.

Terdapat banyak faktor penghambat dalam menjalankan perubahan. Dari mulai level bawah sampai level tertinggi. Namun stategi yang harus dijalankan oleh lembaga yang memiliki peran dalam menjalankan manajemen perubahan ini harus dijalnkan secara tepat. Salah satunya adalah menyampaikan pesan perubahan dengan tepat.Pesan yang disampaikan kepada para manajer upayakan agar supaya pihak-pihak yang terlibat dalam perubahan tersebut memahami apa saja alasan dibelakang tindakan perubahan tersebut, bagaimana 
bentuknya dan bagaimana dampak-dampak yang dapat diduga akan timbul. Dengan adanya penerapan suatu manajemen perubahan di Perguruan Tinggi, yaitumerubah dari keadaan sebelumnya menjadi keadaan yang lebih maju maka Perguruan Tinggi tersebut akan diminati oleh masyarakat. Dan masyarakat juga tidak beranggapan lagi, bahwa Perguruan Tinggi tidak tertinggal lagi dengan pendidikan-pendidikan yang lain.

\section{Saran}

Bersdasarkan kesimpulan di atas, maka saran pada artikel ini ialah bahwa masih banyak faktor lain yang dapat mempengaruhi Pascasarjana UIN STS Jambi, selain dari manajemen strategi perubahan seperti faktor sumberdaya, faktor budaya, faktor pembiayaan, faktor politik, dan faktor lainya pada semua tipe dan level lembaga pendidikan tinggi. Oleh karena itu masih di perlukan kajian yang lebih lanjut untuk mencari faktor-faktor lain apa saja yang dapat memepengaruhi Pascasarjana UIN STS Jambi selain dari faktor yang telah di teliti pada arikel ini.

\section{DAFTAR RUJUKAN}

Abdurrahman, N. H. dan A. S. (2015). Manajemen Strategi Pemasaran. In Manajemen Strategi Pemasaran.

Ahmad Syukri, Maisah, S. (2020). LIFE SKILLS PROGRAM MANAGEMENT IN IMPROVING. International Journal of Research -GRANTHAALAYAH, 8(3), 10-21. https://doi.org/10.29121/granthaalayah.v8.i3.2020.119

Alfan Zuhairini, J. M. (2011). STRATEGIES OF MAINTAINING PROFICIENCY BY TEACHERS OF ENGLISH IN INDONESIA. LiNGUA: Jurnal Ilmu Bahasa Dan Sastra. https://d oi.org/10.18860/ling.v5i2.630

Aminuddin Awang Kechik. (2011). Reformasi Dalam TVET: Perubahan Masa Hadapan. Journal of Edupres.

Anggareni, N. ., Ristiati, N. ., \& Widiyanti, N. L. P. . (2013). Implementasi Strategi Pembelajaran Inkuiri Terhadap Kemampuan Berpikir Kritis Dan Pemahaman Konsep IPA Siswa SMP. E-Journal Program Pascasarjana Universitas Pendidikan Ganesha.

Arifin, M. (2017). STRATEGI MANAJEMEN PERUBAHAN DALAM MENINGKATKAN DISIPLIN DI PERGURUAN TINGGI. 3(1), 117-132.

Artini, Y. D. (2015). Manajemen Sumber Daya Manusia (MSDM) Berbasis Kompetensi sebagai Strategi Membangun Organisasi Kompetitif. EFISIENSI - KAJIAN ILMU ADMINISTRASI. https://doi.org/10.21831/efisiensi.v11i2.3989

Assauri, S. (2011). Manajemen Pemasaran Dasar Konsep dan Strategi. In PT RajaGrafindo Persada, Jakarta.

Dalimunthe, S. F. (2013). Manajemen Konflik Dalam Organisasi. Jurnal Bahas.

Dewi, R. R., \& Kurniawan, T. (2019). MANAJEMEN PERUBAHAN ORGANISASI PUBLIK : MENGATASI RESISTENSI PERUBAHAN. NATAPRAJA. https://doi.org/10.21831/jnp.v7i1.24599

Edison, E., Anwar, Y., \& Komariyah, I. (2016). Manajemen Sumber Daya Manusia. In Manajemen Sumber Daya Manusia.

Einstein, A. (2013). Relativity. In Relativity. https://doi.org/10.4324/9781315886749

Gunanto, D. S. (2013). Sistem pengendalian manajemen. Jurnal Akuntansi Dan Pajak.

Harahap, A. S. H. (2019). Analisis Strategi Peningkatan Kinerja Bagian Sekretariat Pada Dinas Pendidikan, Pemuda dan Olahraga Kota Padang. Jurnal Ilmu Manajemen 
Terapan, 1(1), 69-75.

Hamalik (2010: 29) dalam Baharudin, 2015). (2015). Pengembangan Media Pembelajaran Berbasis Multimedia Interaktif Sekolah Menengah Kejuruan Terhadap Efektif dan Efisiensi Pembelajaran. Jurnal Inovasi Dan Teknologi Pembelajaran.

Hapzi Ali. Nandan Limakrisna. (2013). Metodologi Penelitian ( Petunjuk Praktis Untuk Pemecahan Masalah Bisnis, Penyusunan Skripsi, Tesis, dan Disertasi. In Deeppublish: Yogyakarta.

HUBUNGAN KEPEMIMPINAN, BUDAYA, STRATEGI, DAN KINERJA: PENDEKATAN KONSEP. (2005). Jurnal Manajemen Dan Wirausaha. https://doi.org/10.9744/jmk.7.1.pp.60-73

Indraddin, \& Irwan. (2016). Strategi dan Perubahan Sosial.

Indrawati, A. (2011). Pengaruh Kualitas Layanan Lembaga Pendidikan Terhadap Kepuasan Konsumen. Jurnal Ekonomi Dan Bisnis.

Kotler, P., \& Armstrong, G. (2012). Prinsip-Prinsip PEMASARAN Principle of Marketing. $1-63$.

Kotler, P., \& Keller, K. L. (2009). Manajemen pemasaran Jilid 1. In Jakarta.

Maisah, M., Fauzi, H., Aprianto, I., Amiruddin, A., \& Zulqarnain, Z. (2020). STRATEGI PENGEMBANGAN MUTU PERGURUAN TINGGI. Jurnal Ilmu Manajemen Terapan. https://doi.org/10.31933/jimt.v1i5.202

Mathis, R. L., \& Jackson, J. H. (2012). Manajemen Sumber Daya Manusia. In Manajemen Sumber Daya Manusia.

Muhammad Arifin, Mp. (2017). Strategi Manajemen Perubahan Dalam Meningkatkan Disiplin Di Perguruan Tinggi. Jurnal EduTech.

Muis, M. A., Hussin, Z. H., \& Mohamed, B. A. (2010). Perubahan Generasi dan Perkembangan Demokrasi di Malaysia Pasca Pilihan Raya Umum ke-12. Seminar on Nasional Resilience (SNAR 2010) "Political Managements and Policies in Malaysia."

Muslich, M. (2003). Manajemen Keuangan Modern. In Manajemen Keuangan Modern.

Narsa, I. M. (2014). WHAT IS STRATEGY? Jurnal Pendidikan Akuntansi Indonesia. https://doi.org/10.21831/jpai.v6i1.1788

Nasution, S. (2002). Metode Penelitian. Jakarta: Rineka Cipta.

Nisak, Z. (2004). Analisis Swot Untuk Menentukan Strategi Kompetitif. Analisis Swot Untuk Menentukan Strategi Kompetitif.

PENGARUH PERKEMBANGAN TEKNOLOGI INFORMASI TERHADAP BIDANG AKUNTANSI MANAJEMEN. (2000). Jurnal Akuntansi Dan Keuangan. https://doi.org/10.9744/jak.2.2.pp.127-137

Peter, P. J., \& Olson, J. C. (2013). Perilaku Konsumen dan Strategi Pemasaran. In Salemba Empat.

Pidarta, M. (1997). Studi tentang Landasan Kependidikan. Jurnal Ilmu Pendidikan.

Rahayu, A. (2010). Pengaruh Atribut Produk Wisata Terhadap Kepuasan Wisatawan. Trikonomika.

Sari, F. M., \& Ibrahim, M. (2009). Penerapan Manajemen Perubahan Dan Inovasi. Administrasi Pembangunan.

Suharsimi, A. (2013). Metodologi penelitian. In bumi aksara.

Sumarwan, U. (2003). Perilaku Konsumen: Teori dan penerapannya dalam Pemasaran. Ghalia Indonesia, Jakarta.

Tambunan, P., Suhendi, H., Siswanto, B. E., \& Lisnawati, Y. (2011). Manajemen adaptasi dalam perubahan iklim. Jurnal Analisis Kebijakan Kehutanan.

US, K. A., \& Sohiron, S. (2020). PENDIDIKAN ISLAM DALAM PERSPEKTIF REVOLUSI MODERN DI INDONESIA. JURNAL MANAJEMEN PENDIDIKAN 
DAN ILMU SOSIAL, 1(1), 9-17.

Tjiptono, \& Fandy. (1997). Strategi Pemasaran, edisi kedua. In Andi Ofset.

Tjiptono, \& Fandy. (2015). Strategi Pemasaran. In Yogyakarta: Andi.

Waugh, E., \& Austen, J. (2014). Society. In The Therapeutic Imagination: Using Literature to Deepen Psychodynamic Understanding and Enhance Empathy. https://doi.org/10.4324/9781315879826-8

Wedhasmara, a. (2014). Langkah-Langkah Perencanaan Strategis Sistem Informasi dengan Menggunakan Metode Ward and Peppard. Jurnal Sistem Informasi.

Wibowo, D. H., Arifin, Z., \& Sunarti, . (2015). Analisis Strategi Pemasaran Untuk Meningkatkan Daya Saing UMKM (Studi pada Batik Diajeng Solo). Jurnal Administrasi Bisnis.

Widodo, H. (2017). Manajemen Perubahan Budaya Sekolah. MANAGERIA: Jurnal Manajemen Pendidikan Islam. https://doi.org/10.14421/manageria.2017.22-05

Winardi. (2004). Manajemen Perilaku Organisasi. In Jakarta: Pustaka Binaman Pressindo.

Winardi. (2017). Dampak Pembangunan Kawasan Industri Terhadap Output, Penyerapan Tenaga Kerja, Distribusi Pendapatan dan Kemiskinan Rumah Tangga di Provinsi Jawa Barat. In IPB (Bogor Agricultural University). 